\title{
TRANSMITTING INFORMATION WITHOUT AN INDIVIDUAL MATERIAL CARRIER ${ }^{1}$
}

\author{
Aleksandr A. Shuneyko \\ Komsomolsk-on-Amur State Technical University, Komsomolsk-on-Amur, Russian Federation \\ Olga V. Chibisova \\ Komsomolsk-on-Amur State Technical University, Komsomolsk-on-Amur, Russian Federation
}

\begin{abstract}
The present article deals with the semantic and functional characteristics of a zero sign, which represents a significant and apprehended absence of some symbol in the context, where it was or should be under the mandatory conditions for the existence of this environment. Its characteristics have not been properly described in scientific works, therefore the study, based on the methods of semantic, distributive and communicative analysis, survey and comparison of the features of different units, aimed at filling the gap in the interpretation of types of language units, seems to be a current matter of interest. The authors use the term zero sign to denote a unit that does not have an external form, performs special functions, and is actively represented in various cultural spheres. The article demonstrates the presence of a zero sign in the languages. Its registration is an indispensable condition for the correct interpretation of the context. The absence of anything can report as much information as its presence. A zero sign occupies a special place among the ways of transmitting information without material carriers. The study results ascertain that a zero sign plays an essential role in the extremely complex process of information transmission. In conclusion the authors give a range of applications which are related to the subsequent detailing of the means and methods of information transmission and the prospects for their purposeful use.
\end{abstract}

Key words: information, material carrier of information, zero sign, information transmission.

Citation. Shuneyko A.A., Chibisova O.V. Transmitting Information without an Individual Material Carrier. Vestnik Volgogradskogo gosudarstvennogo universiteta. Seriya 2, Yazykoznanie [Science Journal of Volgograd State University. Linguistics], 2017, vol. 16, no. 3, pp. 248-256. DOI: https://doi.org/10.15688/jvolsu2.2017.3.26

\section{ТРАНСЛЯЦИЯ ИНФОРМАЦИИ БЕЗ ИНДИВИДУАЛЬНОГО МАТЕРИАЛЬНОГО НОСИТЕЛЯ ${ }^{1}$}

\section{Александр Альфредович Шунейко}

Комсомольский-на-Амуре государственный технический университет, г. Комсомольск-на-Амуре, Российская Федерация

\section{Ольга Владимировна Чибисова}

Комсомольский-на-Амуре государственный технический университет, г. Комсомольск-на-Амуре, Российская Федерация

Аннотация. В статье рассмотрены семантические и функциональные характеристики нулевого знака релевантного и воспринимаемого приемниками информации отсутствия некоторого объекта в контексте, где он был или должен быть по обязательным условиям существования данной среды. Поскольку эти характеристики до сих пор не получили адекватного описания в научных трудах, исследование, основанное на 
семантическом, дистрибутивном и коммуникативном анализе, сопоставлении особенностей различных единиц и направленное на восполнение пробела в интерпретации типов языковых единиц, представляется актуальным. Авторами уточняется толкование термина «нулевой знак», обозначающего единицу, которая не имеет внешней формы, выполняет особые функции, активно представлена в различных культурных сферах. Подтверждено наличие нулевых знаков в языковой системе и определено их место среди способов передачи информации без материальных носителей. Показано, что учет нулевых знаков является обязательным условием верной интерпретации контекста и что отсутствие какого-либо материального выражения содержания может сообщать не менее существенную информацию, чем его наличие. Определены возможности применения результатов исследования, которые связаны с последующей детализацией средств и способов передачи информации и с перспективами их целенаправленного использования.

Ключевые слова: информация, материальный носитель информации, нулевой знак, трансляция информации.

Цитирование. Shuneyko A.A., Chibisova O.V. Transmitting Information without an Individual Material Carrier // Вестник Волгоградского государственного университета. Серия 2, Языкознание. - 2017. - Т. 16, № 3. - C. 248-256. - DOI: https://doi.org/10.15688/jvolsu2.2017.3.26

\section{Introduction}

In the humanities there is a generally correct and justified idea, according to which an object, no matter material or mental, can be fixed in memory or perception only with the help of another object. Thus traditional linguistics and semiotics focus on objects which, by their material form, are referred to any meaning that is outside of or related to them. Such objects are called signs and characterized as three-membered structures that include an external form, meaning and denotation. At the same time, in language, speech, and other semiotic systems, there is a set of specific objects, united by an obvious formal similarity - all of them somehow denote something (possess some semantics, transmit information). But the very fact of designation, as a rule, does not have a formal expression by way of actual material carriers, represented precisely in that segment of the text where this designation is carried out. This feature allows to line up these objects, combine them and conditionally consider them as different representatives of the category of absence. The category of absence is a functional semantic category that is represented in situations where the information transmission is not accompanied by material carriers, but is realized outside or apart from them. There are many such situations in real communicative space. Any person encountered them when, for example, he or she evaluated or tried to interpret the interlocutor's silence during a telephone conversation, did not receive a reply letter, did not find things in the usual place, or, pressing the intercom button, did not hear the usual signal.
The realizations of the category of absence in language and speech can be quite strictly enumerated: suppression, gaps, morphological zeros, pauses (spaces), phonological zeros and ellipses of different types. Suppression is the absence of a message about certain facts. Lacuna (gap) is the absence of an object represented in another semiotic system. Morphological zero is the absence of the material expression of the morpheme, which is included in the lexical or grammatical basis of the word. Pause is the absence of verbally expressed speech, a break in the translation of a certain information flow. Phonological zero is the absence of a phoneme in a position where its presence is predetermined by the system. Ellipse is the absence of a word or word combination, the presence of which is restored from syntactic or situational contexts.

Even from these extremely concise definitions it can be seen that the listed units belong to different levels of the language in their functionality, have different degrees of complexity in their organization and are characterized by local features of explication and communicative status. Structurally, morphological and phonological zeros are the simplest, and various types of pauses are the most complex. The latter were noted by I. Brodsky in the poem "Homage to Yalta" as a vivid characteristic of speech:

His speech consisted, on the whole, of pauses that always made you feel uneasy, since we ordinarily interpret silence to mean a person's mind is busy working. And his, in fact, was nothing but pure silence. You'd soon begin to get a feeling of your own dependence on this quietness, and that would irritate a lot of people. [Collected Poems...] 
From the passage it is clear what semantic complexes and functional communicative devices can be transmitted by pauses, what meanings they can be given in the conception of a person perceiving them.

All these units are traditional, recognizable and somehow receive semantic content from the context in which they function. Virtually all of them can be identified by the potential or real deformations of contexts that their presence cause and can be restored from the context. In this sense, being undoubtedly zeros, they partially delegate their material form to the context dispersing it there. That is, the absence of their local form is partially replaced by the presence of a diffusely dispersed form. For example, an elliptic element is represented by features of a communicative situation or by its verbally expressed double. In addition, many of these units in oral and written speech can have their formal substituents. So the figure of suppression can be replaced by an ellipsis, an ellipse by a dash, and a pause by a space. The nature of these elements, not literally and identically, but with a measure of essential similarity resembles the nature of presupposition and modality. The latter also do not have separate, independent external semantic forms of expression that serve only their semantics; it is dispersed in the syntactic structure, its content and predicative core. Just as we can name units that fix presupposition but are not specialized in transferring only it, we can name the units that fix the transfer of all the listed zeros, although they are not specialized in their implementation.

The analysis of the absence category realizations has a respectable linguistic history. Here come the names of only a few Russian researchers who have considered (and continue to consider) the listed units in their various manifestations (sometimes differently calling them). We should stress that each list of names must be concluded with the formula "and many others." Lacunarity became the object of scientific analysis in the works of G.V. Bykova [1999], V.N. Ryabov [1997], Yu.A. Sorokin [2003]. Morphological zeros were described by A.A. Zaliznyak [2002], E.A. Zemskaya [2004], M.A. Kosogorova [2013]. The pause was analyzed by T.M. Nikolaeva [1973], Yu.E. Kochenkova [2011], E.S. Chernyavskaya [2013]. The graphic embodiment of the pause, that is, the gap, was studied by A.B. Penkovsky and B.S. Shvartskopf [1980]. Phonological zeros were investigated by M.V. Panov [1967], A.A. Reformatsky [1979]. Ellipsis was considered by T.A. Starodubova [2009], Yu.A. Belchikov [2003], and A.P. Skovorodnikov [1973].

There exists one more way of embodiment of a category of absence - a zero sign. Until now, it has not attracted the attention of researchers and has not been perceived as a separate independent semiotic unit. The characteristics of this zero sign are interesting in themselves, because this unit allows us to perceive the communicative and semiotic space surrounding us with a greater measure of consistency and adequacy. In addition, it is worth understanding how it coordinates with the concepts enumerated above, since it makes it possible to present them from a new angle and to find differential features.

\section{Differential features of the zero sign}

To characterize the zero sign in the semiotic aspect we should firstly pay attention to its differential characteristics, and then we would indicate how it is included in a set of formally similar units. The choice of the analyzed object's name is connected with two factors:

1. The attribute zero is used in semiotics and thus the term organically fits into the semiotic tradition. A zero denotation is a situation in which a name can be attributed to an object existing in that segment of the world that is commonly called reality, for example, the names of mythological characters. "A term may have zero content, for example, a round square. The classification of consistently conceivable objects, called this way, is an empty class. But many terms - for example, a unicorn and an unreasonable animal that laughs - have both zero denotation and zero content. The objects that can be properly named in this way are conceivable without contradiction" [Lewis, 2001, p. 232].

2. The term at such nomination retains a high degree of authenticity with respect to terms that refer to the associated concepts in linguistics.

A zero sign is a meaningful, functionally and semantically independent absence of an object or action within the framework of a certain text, the necessity of its presence is strictly prescribed by social norms (rules) or context. In other words, it 
is the absence of an object in a context which irreducible characteristic it became during a certain stage of its functioning and within which it was perceived as its obligatory component. At that, the fact of its obligation is fixed in the consciousness of the language community that contact with this context. The semantics of a zero sign is not inferior in its role and informative saturation to the semantics of a materially expressed sign in the traditional sense of the word. A zero sign has no tangible signifier, but at the same time it transmits information which unites it with the units listed above.

Here comes some illustrations of the stable presence of zero signs in various semiotic systems.

Graphical systems. The perception of a constantly reproduced graphical text is stably imprinted in the consciousness of the information receiver. Any changes in this text connected with the removal of something from it become zero signs. For example, the logo of the Literaturnaya Gazeta in the USSR included images of two profiles - Pushkin's and Gorky's. After the perestroika, Gorky's profile was removed from the logo (now, thanks to the efforts of the current editor-in-chief of the newspaper it is restored again). The absence of Gorky's profile on the $\log$ o of the newspaper in recent years was a zero sign with semantics: "the newspaper tells of the literature that has left the diktat of the party organization and functions outside the strict control of the Communist Party." This semantics could not have arisen if the long tradition of perceiving the logo did not link it to the profile of Gorky and the corresponding ideological guidelines. Similarly, an empty space in a newspaper or magazine on the place of the material may point to censorship.

Architectural systems. The removal of an object from the existing architectural system gives rise to the occurrence of a zero sign. The examples of it are the monuments and structures of one politically oriented era, which are demolished during the other. On December 5, 1931 in Moscow, was blown the Cathedral of Christ the Saviour. Until the nineties for Muscovites, who passed along Volkhonka or nearby, it was a zero sign with semantics "the state-imposed domination of atheism and the rejection of the historical past." Now, for some people who go along the same streets a zero sign is the swimming pool Moscow, which was on the site of the cathedral, with the semantics "a return to Christian values."

In the architectural space, zero signs are actively produced during and after the demolition of ideologically oriented monuments: the demolished monument to Kalinin near the Institute of Linguistics of the Russian Academy of Sciences, the demolished monument to Dzerzhinsky on the Lubyanka and many others. After the events of September 11, 2001, the Twin Towers became a zero sign as well.

Alarm and signaling systems. Here, by virtue of a special treaty, a zero sign can be the absence of any object previously marked with one or another semantics. For example, Lorna Dun, the heroine of the eponymous novel, in a difficult life situation warns her lover, reminding him of a tree with three bird's nests: watch it, if one of the nests disappears, I need help. The absence of a nest, to which a certain semantics is assigned in advance, is a zero sign. Similarly, in the well-known scene from "Seventeen Moments of Spring", the presence / absence of a flower on the windowsill was a sign of the possibility / impossibility to visit the secret address.

Systems of socially oriented behavior. Social behavior is always subject to hard or soft etiquette. Any omitted element of this etiquette becomes a zero sign. For example, on meeting your neighbor traditionally bows to you or takes off his hat, your fitness partner, leaving the locker room, says goodbye to you. If one of them does not do it one time, the lack of action is a zero sign which you immediately begin to interpret, guessing why it happened, what significance this zero sign has, what is behind it. There are plenty of examples of zero signs in social behavior; they broadcast a variety of things, including politically oriented meanings. When in the USSR a pioneer at school did not wear a tie, its absence was a zero sign of rejecting ideological dictatorship, motivated by one or other reasons (similarly with the Komsomol badge). The absence of clothes on E. Poe in a well-known vital event was a zero sign of environmental rejection. The refusal to give a hand for a handshake to a rascal is a zero sign of disapproval of his life position. To continue sitting during the execution of a national anthem is a zero sign of non-accepting a political system. A zero sign can be a sign of belonging to a particular social group. A striking example of this is nudists, 
for the appearance of whom zero signs are characteristic. Shaved skull, too, may indicate membership in various groups.

Systems of everyday behavior. Everyday behavior is always based on stereotypes. Any deviation from the stereotype generates a zero sign. For example, it is believed that food should be salted. If you are served an unsalted dish at home or in a restaurant, you immediately notice it. The absence of salt is a zero sign which you interpret in different ways: something happened to the cook, he is inattentive, his thoughts are occupied with something different, etc. There are many examples of zero signs in everyday behavior. When you are used to seeing a certain girl decorated with a lot of jewelry and suddenly, meeting her, you do not notice a single one on her, the very absence of jewelry will be a zero sign with the semantics "something has happened" (a more specific reading of which is determined by the level of your knowledge about this person or her desire to clarify the situation). Similarly with cosmetics: if you are accustomed to see a girl with makeup, and one day you saw her without it, the lack of make-up is a zero sign. In the context of everyday behavior, a zero mark is the absence of any object which constantly and invariably accompanies a particular person, which has become an integral part of his / her image: glasses, a bag, a cane, a handkerchief, tights, a tie, etc.

The situation, within the framework of which the whole epoch with the events, personalities and priorities composing it became a zero mark, is fixed in the textbook lines of G. Ivanov:

Невероятно до смешного:

Был целый мир - и нет его.

Вдруг - ни похода ледяного,

Ни капитана Иванова,

Ну, абсолютно ничего!

It's both implausible and quite plain:

The whole world suddenly is gone.

Ceased to exist the ice campaign,

And there is no captain's name,

Well, absolutely none at all!

None in this case is the name of a zero sign (or the sign of a sign), the semantics of which is disclosed by the previous context. The poetic style of G. Ivanov as a whole is oriented to the embodiment of zero signs.
If the life of a particular person is perceived as a text in a strict semiotic sense, then, in principle, any memory of this person about nonexistent objects can be assigned to the set of zero signs. We can assume that, in the same way as there are commonly used and individual signs, there exist commonly used and individual zero signs. Hamlet in the first lines of his famous dialogue: "To be or not to be" in the second position calls exactly a zero sign, mentions the category of absence or total nonexistence, which in the perception of this character gets a suitable semantization through a set of relevant characteristics.

The number of examples can be multiplied. Obviously, the necessary condition for the existence of a zero sign is the previous replacement of its position by another sign and / or a special agreement on the meaning originally assigned to it. It is also important that the sign, which is primary for the zero sign, should be substantially updated for a certain part of the language collective. In other words, it must be persistently observed and associated with certain information. In this case, a zero sign itself (as, in fact, a materially expressed sign) functions in the consciousness of the language collective (or its specific representative) for the period of time during which its denotation - the original object that it replaces - continues to be actual.

It can be seen from the examples that zero signs can arise spontaneously, unintentionally and be the result of purposeful actions, that is, they have a distinctly natural and unambiguously artificial character. In this sense, they are not different from the signs traditionally considered in semiotics. The attribution depends on the specific circumstances of the occurrence. The fact that the representatives of collectives are capable of consciously producing linguistic signs emphasizes that the collective understands their functionality.

The presence of zero signs is recognized by the members of language groups. This is manifested in the fact that people do not only focus their attention on them, but also develop special procedures for restoration of information which these signs replace, draw conclusions from their availability. A vivid example of this is a "reading between lines" technique that existed in the USSR. In a totalitarian state, the mass media 
are in the grip of harsh political censorship. In such a situation, it is impossible to publish there any information which is undesirable for the state. But the population of the USSR developed a special technique for extracting from the media the information that was absent in them. It was called "reading between the lines." It is based on the accounting and analysis of what is not mentioned. In general, this technique was as follows. For example, newspapers persistently mention a Western leader in neutral contexts. If, at some point, they stop doing it, from the very fact of these missing references, from zero signs it is concluded that this leader has given utterance or performed an act directed against the USSR. Newspapers do not report this deed, but the very fact of its availability becomes known through zero signs. The maxims says what is held back is much more significant than what is said.

\section{Comparison of zero signs with units implementing the category of absence}

Probably, zero signs function only in the languages that somehow serve human communication. They should not be confused with the notion of materially non-expressed signs validated in linguistics, for example, the absence of a verb-ligament ecmb (to be) in the present tense in Russian, morphemic or phonemic zeros, and ellipses. The latter represent an implicit, indirect realization of stably reproducible samples (material units) in exact accordance with their intrinsic meaning. In fact, in situations of their use, the signifier is omitted, and the signified is preserved strictly in accordance with its original (the same as the materially expressed variant has) characteristics. In the case of zero signs, a new meaning is produced, often the opposite of the meaning of the missing sign or somehow transforming it. Besides, you should not mix a zero sign with a pause. The absence or presence of a pause by itself can be a zero sign, for example: a text without gaps in avant-garde poetry.

The concept of the contextually determined variability of any sign allows formulating these differences as follows. Morphemic or phonemic zeros and ellipsis are contextually conditioned variants of materially expressed signs, preserving the identical semantics with them. A zero sign is not a variant of its original pattern; their semantics vary significantly, although in some cases it can have common components. Using a common language metaphor, a zero sign can be called a ghost or a phantom of the original sign. The legality of this metaphorical substitution is determined by two factors.

1. A zero sign is a non-material product of the initial material sign which appeared after the complete destruction or exclusion from the context of the second.

2. In this case, a zero sign acquires an independent existence, a special meaning, and retains the ability of any sign to influence the native speakers, but within the framework of this new meaning, through it or with the support of it.

In the pragmatic aspect, the zero sign plays an important role, has a significant pragmatic component. It becomes a translator not so much of the tradition (although of it as well), as a fixer of a changing tradition; it signals to native speakers about transformations of the actual context. It becomes a clip between two variants of this context - the one that it could remain in the absence of corresponding changes and the one it became at their availability. In this case, the clip acts as a marker which denotes the very fact of mutual simultaneous existence of possible and real worlds.

Syntagmatics of the zero sign also proves to be specific. It turns out to enter into syntagmatic interactions not only with signs of a similar nature (as is the case with signs in the traditional sense), but with the actual context of the traditionally understood and perceived signs, since outside this context it does not exist. As an analogue of this syntagmatic interaction one can consider the contact juxtaposition of signs from different semiotic systems.

At the same time, because the presence of a zero sign is significantly conditioned by the context means that, on the one hand, it is another characteristics which makes it possible to combine it with the units listed above into a single series, and on the other hand, it is the basis on which one of the variants of their typology can be built. The classification can be carried out on the criterion of contextual attribution which determines the existence of any of the above units and indicates their presence. The contextual attribution 
determines the starting points, reliance on which explicates the units in the linguistic consciousness, no matter whether it is the consciousness of a specialist or an ordinary language carrier. The contextual attribution is something on the basis of which the units listed above are restored, identified and acquire the status of significant ones. In this respect, the following characteristics can be formulated:

- A phonological zero acquires the status of an independent unit and is restored as a result of the correlation of this minimal context (within the word) with other ways of its realization in synchrony within the boundaries of one language.

- A morphological zero acquires the status of an independent unit and is restored as a result of the correlation of this minimal context (within the word) with other ways of its realization in synchrony within the boundaries of one language.

- A pause acquires the status of an independent unit and is restored as a result of the correlation of units with different material objectifications in the contexts of varying degrees of breadth and complexity in synchrony within the boundaries of one language.

- An ellipsis acquires the status of an independent unit and is restored as a result of the relationship between different ways of realizing the same context in synchrony within the boundaries of one language.

- A zero sign acquires the status of an independent unit and is restored as a result of the relationship between the different ways of existence of two contexts in diachrony within the boundaries of one language or several languages.

- The lacuna acquires the status of an independent unit and is restored as a result of the relationship between different languages (or functional varieties of the same language) in synchrony and diachrony.

Without denying the possibility that the classification of the units in which the category of absence is realized can be carried out on the basis of a number of other significant criteria, we note that a zero sign among the considered ones turns out to be the most complicated unit. Its hierarchical position is determined by the number and nature of the constituents, as well as by their original variability and nonverbalized semantics. The complexity of a unit, in turn, directly affects the probability and adequacy of its perception by different representatives of the language community. As a particular consequence of this fact, it can be suggested that some features of zero signs can be concretized and refined if one considers their characteristics in a series of the juxtaposed characteristics of the listed units. In particular, a lacuna, like a zero sign, in case of its awareness by the speaker of a certain language, can also be considered as a clip between possible languagesworlds which demonstrates the probabilistic diversity of existing language systems. In the syntagmatic aspect, one can also find an analog: a lacuna, like a zero sign, in the conception of a native speaker can be associated with the actual context of this language, and not with other lacunas, that is, not with similar but with different units.

\section{Zero signs and cultural context}

The nature of the origin of natural zero signs in the context of culture reveals a unity that signals the identity of their initial semiotic nature. All zero signs are the result of catastrophes or protests which are often related to each other and act as different sides of one destructive action. Catastrophes can be global and local in nature. The level of the catastrophe directly predetermines the degree of dissemination of a zero sign in the society and its relevance for the collective. So, global catastrophes - the destruction of the Cathedral of Christ the Savior or Twin Towers - generate zero signs the presence of which is realized and interpreted by whole collectives. And local catastrophes - one person took offense at the other and did not shake hands with him - generate zero signs the presence of which is realized and interpreted only by a small group. But in the process of local interaction, there function many typical and widely-spread zero signs, one way or another read by the whole community. For example, a barefoot person on the streets of a large modern city will certainly attract the attention of the masses not by what he has, but by what he has not - the lack of shoes in which the onlookers will immediately begin to read either membership of a particular sect, or a specific worldview set.

\section{Conclusion}

The interpretation of a zero sign implies the knowledge of the system, its adequate reading, the perception of the context and the mandatory 
presence of cultural memory. The semantics of a zero sign consists of stating the fact of the absence of something and fixing the actual or imaginary reasons for this absence. The reasons for the absence give rise to certain estimates which accompany zero signs in the same way as all the other signs. With respect to the zero sign, one cannot say that its external form is dispersed in the context. It is simply absent. The form is the absence of form, perceived as an unsubstituted position, a gap in place of the one-time or foreseeable (obligatory) object. The analysis of specific texts and situations is incomplete without taking into account zero signs.

A zero sign is a non-material, devoid of a material embodiment reminder of what existed before or should be; the fact of its destruction, absence and the causes of destruction. The number and nature of zero signs noticed by a particular person is directly related to the level of his / her linguistic and cultural competence, can characterize this level. The reference to the zero sign and the need to interpret it reflects the positive tendency of a person to look back, to correlate what was with what is, and draw conclusions from this. The presence of such conclusions is a consequence of the functional nature of a zero sign.

\section{NOTE}

${ }^{1}$ The research was funded by the Government of Khabarovsk region, agreement of July 11, 2016 no. $94 / 2016$ on the grant for academic research in the humanities.

Исследование проведено при поддержке Правительства Хабаровского края, договор от 11.07.2016 № 94/2016 Д о предоставлении гранта на проведение научных исследований в области гуманитарных и общественных наук.

\section{REFERENCES}

Belchikov Yu.A. Ehllipsis [Ellipsis]. Russkiy yazyk. Entsiklopediya [Russian Language. Encyclopedia]. Moscow, Drofa Publ., 2003, pp. 638-639.

Bykova G.V. Vyyavlenie vnutriyazykovykh lakun (na materiale russkogo yazyka) [Identification of Intralinguistic Lacunae (on the Material of the Russian Language)]. Blagoveshchensk, Izd-vo Amurskogo gos. un-ta, 1999. 76 p.

Chernyavskaya E.S. Osobennosti chleneniya rechevogo potoka $\mathrm{v}$ radioreklame [Partitioning of the
Speech Stream in Radio Advertising]. Vestnik Volgogradskogo gosudarstvennogo universiteta. Seriya 2, Yazykoznanie [Science Journal of Volgograd State University. Linguistics], 2013, no. 1, pp. 46-50. Collected Poems in English by Joseph Brodsky.

URL: http://www.nytimes.com/books/first/b/brodskycollected.html (accessed 18 May 2017).

Kochenkova Yu.E. Pauzirovanie v publichnoy rechi uchenykh, propovednikov, akterov: po rezultatam ehksperimenta [Pausing in Public Speech of Scientists, Preachers, Actors, According to the Results of the Experiment]. Yazyk. Slovesnost. Kultura [Language. Philology. Culture], 2011, no. 1, pp. 51-64.

Kosogorova M.A. Morfologicheskiy nul v yazyke pular: klassifikatsiya $\mathrm{i}$ ispolzovanie [Morphological Zero in the Pullar Language: Classification and Use]. Afrikanskiy sbornik statey [The African Collection of Articles]. Saint Petersburg, Muzey antropologii i etnografii RAN Publ., 2013, pp. 340-349.

Lewis K.I. Modusy znacheniya [Value Modes]. Stepanov Yu.S. Semiotika: Antologiya [Semiotics: Anthology]. Moscow, Akademicheskiy Proekt Publ.; Ekaterinburg, Delovaya kniga Publ., 2001, pp. 227-241.

Nikolaeva T.M. Smyslovoe chlenenie teksta i ego individualnye varianty [Semantic Division of the Text and Its Individual Variants]. Semiotika i struktura teksta [Semiotics and Structure of the Text]. Wrociaw, Ossolineum Publ., 1973, pp. 71-79.

Panov M.V. Russkaya fonetika [Russian Phonetics]. Moscow, Prosveshchenie Publ., 1967. $440 \mathrm{p}$.

Penkovsky A.B., Shvartskopf B.S. Psikholingvisticheskoe soderzhanie remarki "pauza" v dramaticheskom tekste [The Psycholinguistic Content of the Pause in the Dramatic Text]. Vsesoyuznyy simpozium po psikholingvistike [AllUnion Symposium on Psycholinguistics]. Moscow, Izd-vo Mosk. un-ta, 1980, pp. 65-68.

Reformatskiy A.A. Ocherki po fonologii, morfonologii i morfologii [Essays on Phonology, Morphonology and Morphology]. Moscow, Nauka Publ., 1979. 102 p.

Ryabov V.N. Russkie intrayazykovye lakuny (formalno-semanticheskiy aspekt) [Russian Intralinguistic Lacunae (Formal-Semantic Aspect)]. 1997. URL: http://cheloveknauka.com/russkieintrayazykovye-lakuny-formalno-semanticheskiyaspekt. (accessed May 18, 2017).

Skovorodnikov A.P. O kriterii ehlliptichnosti v russkom sintaksise [On the Criterion of Ellipticity in Russian Syntax]. Voprosy yazykoznaniya [Topics in the Study of Language], 1973, no. 3, pp. 114-123.

Sorokin Yu.A. Lakuny: eshche odin rakurs rassmotreniya [Lacunae: Another Aspect of Study]. Lakuny v yazyke i rechi: Sbornik nauchnykh trudov 


\section{ДИСкУССИи}

[Lacunae in Language and Speech: Collection of Academic Works]. Blagoveshchensk, Izd-vo BGPU, 2003, pp. 3-11.

Starodubova T.A. Ehllipticheskie slozhnye predlozheniya [Elliptical Compound Sentences]. URL: http:/cheloveknauka.com/ellipticheskie-slozhnyepredlozheniya. (accessed May 18, 2017).

Zaliznyak A.A. "Russkoe imennoe slovoizmenenie" s prilozheniem izbrannykh rabot po sovremennomu russkomu yazyku i obshchemu yazykoznaniyu ["Russian Nominal Word Change" with the Application of Selected Works on the Modern Russian Language and General Linguistics]. Moscow, Yazyki slavyanskoy kultury Publ., 2002, vol. I-VIII. 275 p.

Zemskaya E.A. Russkaya razgovornaya rech: lingvisticheskiy analiz i problemy obucheniya [Russian Colloquial Speech: Linguistic Analysis and Teaching Problems]. Moscow, Nauka; Flinta Publ., 2004. 240 p.

\section{Information about the Authors}

Aleksandr A. Shuneyko, Doctor of Sciences (Philology), Professor, Department of Linguistics and Intercultural Communication, Komsomolsk-on-Amur State Technical University, Prosp. Lenina, 27, 681013 Komsomolsk-on-Amur, Russian Federation, a-shuneyko@yandex.ru, http://orcid.org/0000-00015467-2214

Olga V. Chibisova, Candidate of Sciences (Cultural Studies), Associate Professor, Department of Linguistics and Intercultural Communication, Komsomolsk-on-Amur State Technical University, Prosp. Lenina, 27, 681013 Komsomolsk-on-Amur, Russian Federation, olgachibisova@yandex.ru, http://orcid.org/ 0000-0002-2709-2465

\section{Информация об авторах}

Александр Альфредович Шунейко, доктор филологических наук, профессор кафедры лингвистики и межкультурной коммуникации, Комсомольский-на-Амуре государственный технический университет, просп. Ленина, 27, 681013 г. Комсомольск-на-Амуре, Российская Федерация, a-shuneyko@yandex.ru,http://orcid.org/0000-0001-5467-2214

Ольга Владимировна Чибисова, кандидат культурологии, доцент кафедры лингвистики и межкультурной коммуникации, Комсомольский-на-Амуре государственный технический университет, просп. Ленина, 27, 681013 г. Комсомольск-на-Амуре, Российская Федерация, olgachibisova@yandex.ru, http://orcid.org/0000-0002-2709-2465 